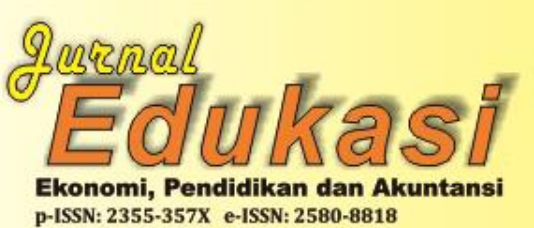

Program Studi Pendidikan Akuntansi

Fakultas Keguruan Dan Ilmu Pendidikan UNIVERSITAS GALUH CIAMIS

p-ISSN: 2355-357X e-ISSN: 2580-8818

https://jurnal.unigal.ac.id/index.php/edukasi

\title{
PELAKSANAAN PENGENDALIAN PENJUALAN MELALUI OPTIMALISASI PERENCANAAN PENJUALAN
}

\author{
Oleh: \\ Firman Aryansyah \\ Program Studi Pendidikan Akuntansi FKIP Universitas Galuh \\ Jl. R.E. Martadinata No. 150 Ciamis \\ Email : Firman_aryansyah13@yahoo.com \\ Sejarah Artikel: Diterima Agustus 2019, Disetujui September 2019, Dipublikasikan November 2019
}

\begin{abstract}
ABSTRAK
Perencanaan diperlukan untuk dapat mengkoordinasikan dan mengarahkan kegiatan penjualan. Perencanaan membantu perusahaan mendapatkan cara yang tepat untuk menghindari kerugian dan mempertahankan keberlangsungan kegiatan usahanya. Perencanaan dalam perusahaan adalah dasar dalam berjalannya fungsi pengendalian. Sebelum perencanaan penjualan disusun, tindakan pertama yang harus dilakukan terlebih ialah dengan melakukan ramalan penjualan (sales forecast) untuk dapat memperkirakaan periode yang datang. Ramalan penjualan merupakan dasar dalam penyusunan rencana penjualan, dengan mempertimbangkan sumber daya yang ada serta strategi penjualan untuk dapat mencapai tujuan perusahaan. Pentingnya peramalan penjualan karena Semakin banyaknya jumlah persaingan perusahaan diambang perdagangan bebas dan semakin komplitnya permasalahan dalam penjualan. Penelitian ini membahas tentang salahsatu kegiatan perencanaan yakni untuk mengetahui pengaruh perencanaan penjualan terhadap pengendalian biaya penjualan. Penelitian ini menggunakan metode deskriptif kuantitatif menggunakan angket dan studi dokumentasi pada CV. Rahayu sebuah perusahaan manufaktur skala kecil yang mengolah berbagai penganan berbahan dasar tepung tapioca $(a c i)$ di kecamatan Cijeungjing Kabupaten Ciamis. Penelitian ini menyimpulkan bahwa penjualan sebagai target pencapaian perusahaan dapat dikendalikan jika perusahaan melakukan perencanaan atas penjualan melalui upaya-upaya terhadap pengawasan dalam hal harga, kepuasan pelanggan, segmentasi pasar, serta selera konsumen terhadap produk yang dijualnya.
\end{abstract}

Kata Kunci: perencanaan, pengendalian penjualan, manufaktur, penjualan.

\section{ABSTRACT}

Planning is very important to coordinate and direct sales activities. Through planning, a company might take the right way to avoid loss or maintain its survival. It is because planning is the basis for the functioning of control. The first action that must be taken before the sales planning is prepared that is the sales forecast is done first for the coming period. Sales forecasts will be used as a basis in preparing sales plans, taking into account existing resources and sales strategies to achieve company goals. In this uncertain economic situation, sales forecasting is increasingly important because the amount of competition is increasingly on the verge of free trade and the more complex problems in sales. This study discusses one of the main planning activities namely to find out how the effect of sales planning on controlling sales costs. This research uses a quantitative descriptive method using a questionnaire and documentation study on a CV. Rahayu is a small scale manufacturing company that processes a variety of tapioca flour (aci) snacks in Cijeungjing subdistrict of Ciamis Regency. This research concludes that sales as a target of company achievement can be controlled if the company plans sales through efforts to control in terms of price, customer satisfaction, market segmentation, and consumer tastes of the products it sells.

Keywords: planning, sales control, manufacturing, sales. 


\section{PENDAHULUAN}

Semua perusahaan beroperasi untuk mencapai suatu tujuan tertentu. Apakah itu laba yang memuaskan, pelayanan kepada masyarakat, dan sebagainya. Hal tersebut merupakan suatu tantangan bagi para pelaku bisnis dalam melakukan kegiatan operasional perusahaannya sehingga sasaran dan tujuan yang telah digariskan dapat dicapai secara optimal, maka setiap perusahaan dituntut untuk memaksimalkan semua sumber daya secara optimal untuk meningkatkan kemampuan bersaing perusahaan.

Penjualan merupakan kegiatan pokok dan utama perusahaan sebagai bagian upaya memperoleh laba sehingga tujuan tercapai.

Swasta, (2001:12) menyebutkan bahwa "Penjualan adalah suatu tindakan atau kecakapan untuk mempengaruhi orang-orang untuk mau membeli barang yang ditawarkan dan saling menguntungkan walaupun sebelumnya tidak terpikat untuk membeli barang tersebut tetapi akhirnya tertarik membeli". Sehingga memerlukan adanya suatu perencanaan yang baik agar penjualan, dapat mencapai target atau nilai penjualan yang telah ditetapkan. Perusahaan menetapkan target pernjualan sebagai bagian dari rencana kerja yang harus dipenuhi untuk periode pencapaian setiap tahunnya berdasarkan pada pesanan konsumen baik langsung maupun tidak langsung. Kemampuan perusahaan untuk meyakinkan calon konsumen sangat penting melalui berbagai upaya promosi.

Penjualan sebagai bagian dari fungsi kegiatan pemasaran sangat penting dan menentukan bagi perusahaan dalam mencapai tujuan yakni memperoleh laba sehingga mampu menjaga keberlangsungan perusahaan. Sebagai suatu kegiatan yang ditujukan untuk mendapatlkan pembeli, mempengaruhinya dan memberikan petunjuk sehingga pembeli dapat memenuhi kebutuhannya dengan produk baik barang maupun jasa yang mereka ttawarkan serta mengadakan kesepakatan mengenai harga yang menguntungkan bagi kedua belah pihak. Salah satu komponen yang berhubungan dengan aktivitas penjualan produk adalah biaya penjualan.

Untuk itu perusahaan harus dapat menentukan keputusan yang tepat dengan strategi dan perencanaan di bidang penjualan produk. Oleh karena pentingnya penjualan maka banyak perusahaan yang menekankan kegiatan penjualannya sebagai salah satu aktivitas utama perusahaan seperti halnya dengan kegiatan lainnya.

Pengendalian perlu dilakukan pada setiap perusahaan agar rencana dan kebijakan yang telah dirancang dan ditetapkan sebelumnya tidak menyimpang dalam pelaksanaannya. Penjualan merupakan suatu kegiatan yang dinamis disertai dengan kondisi penjualan yang mudah terpengaruh dengan kejadian di sekitarnya. Oleh karena itu pengendalian terhadap penjualan perlu diterapkan sebagai implementasi dari evaluasi kinerja para karyawan perusahaan

Perencanaan dalam penjualan meliputi berbagai kegiatan diantaranya penyusunan anggaran penjualan, penyusunan metode penjualan yang dapat meningkatkan permintaan pelanggan, syarat-syarat dalam penjualan dan kebijakaan perusahaan dalam penetapan harga agar mampu bersaing dengan produk sejenis lainnya.

Ramalan penjualan merupakan dasar bagi seluruh anggaran. Estimasi atau perkiraan yang akurat tentang jadwal produksi dan tentang biaya yang harus dikeluarkan tergantung pada penjualan yang diramalkan secara terperinci dan tepat dalam nilai uang dan dalam unit. (Horngren dalam Saragih, 2009: 200)

Pengendalian dalam penjualan merupakan suatu studi analisis atas kegiatan penjualan perusahaan, perusahan membandingkan rencana dengan realisasinya serta kebijaksanaan seperti apa yang dapat diambil oleh perusahaan sebagai tindak lanjut untuk mencapai target penjualan yang dikehendaki, dengan biaya yang efisien, agar menghasilkan laba. Perencanaan dan pengendalian penjualan di perusahaan biasanya dilakukan oleh controller. Peran controller dalam menetapkan perencanaan berdasarkan informasi yang diperolehnya dari kegiatan penjualan tahun lalu.

Pengendalian penjualan meliputi analisa, penelaahan, dan penelitian yang diharuskan terhadap kebijaksanaan, prosedur, metode, dan pelaksanaan yang sesungguhnya untuk mencapai volume penjualan yang dikehendaki, dengan biaya yang wajar, yang menghasilkan laba kotor yang diperlukan untuk mencapai hasil pengembalian yang diharapkan atas investasi. (Willson and (Campbell dalam Gunawan, $2005: 259$ ) 
Berdasarkan data yang diperoleh selama lima tahun terakhir (2014 s.d 2018) penjualan perusahaan selalu mengalami kenaikan dari tahun ke tahun. sedangkan, laba bersih yang dihasilkan mengalami fluktuasi sebagaimana disajikan pada tabel 1 di bawah ini.

Tabel 1:

Laporan Laba Rugi CV Rahayu

(Dalam Jutaan Rupiah)

\begin{tabular}{|c|c|c|c|c|c|c|c|c|c|c|}
\hline \multirow[t]{2}{*}{ Keterangan } & \multicolumn{10}{|c|}{ Tahun } \\
\hline & 2014 & $\%$ & 2015 & $\%$ & 2016 & $\%$ & 2017 & $\%$ & 2018 & $\%$ \\
\hline Penjualan & 241.140 & 44.94 & 250.00 & 66.66 & 260.550 & 82.45 & 295.000 & 85.96 & 520.000 & 93.04 \\
\hline HP Penjualan & 100.000 & 55.06 & 119.989 & 33.34 & 120.000 & 14.04 & 142.416 & 14.04 & 280.960 & 6.96 \\
\hline Laba kotor & 141.140 & & 130.011 & & 140.550 & & 152.584 & & 239.04 & \\
\hline Biaya-biaya & & & & & & & & & & \\
\hline $\begin{array}{l}\text { - Administrasi } \\
\text { dan umum }\end{array}$ & 12.00 & 35.29 & 17.50 & 38.46 & 19.00 & 35.19 & 20.25 & 30.02 & 22.00 & 29.53 \\
\hline - Gaj pegawai & 20.00 & 58.82 & 25.00 & 54.95 & 30.00 & 55.56 & 40.00 & 59.30 & 45.00 & 45.00 \\
\hline $\begin{array}{l}\text { - Peralatan } \\
\text { - Lain-lain }\end{array}$ & 2.0 & 5.88 & 3.0 & 6.59 & 5.0 & 9.26 & 7.200 & 10.67 & 7.500 & 7.500 \\
\hline $\begin{array}{l}\text { Jml biaya- } \\
\text { biaya }\end{array}$ & 34.00 & & 45.50 & & 54.00 & & 67.45 & & 74.50 & \\
\hline Laba bersih & 107.140 & 20.3 & 84.51 & 16.01 & 86.55 & 16.40 & 85.13 & 16.13 & 164.540 & 31.12 \\
\hline
\end{tabular}

Meskipun transaksi penjualan pada perusahaan mengalami kenaikan sepanjang lim tahun terakhir, secara perencanaan masih belum memenuhi target yang ditetapkan manajemen sehingga berimbas pada realisasi perolehan laba bersih yang berfluktuasi.

Berdasarkan data di atas dapat dijelaskan tujuan penelitian ini diantaranya untuk mengetahui:

1. Pelaksanaan perencanaan penjualan yang diterapkan oleh perusahaan.

2. Penetapan pengendalian biaya penjualan oleh perusahaan.

3. Pengaruh perencanaan penjualan terhadap pengendalian penjualan pada perusahaan.

Penelitian ini penting sekali dilakukan untuk dapat memberikan gambaran seberapa penting pelaksanaan perencanaan penjualan berkontribusi terhadap operasionalisasi perusahaan dalam mengefektifkan penjualan untuk beroleh laba sebagai upaya tetap eksisnya perusahaan.

\section{METODE PENELITIAN}

Penelitian ini menggunakan metode deskriptif, karena dilakukan dengan cara mengumpulkan data-data secara sistematis, fakta mengenai objek serta menginterprestasikan yang diteliti Dalam upaya melihat peristiwa yang terjadi pada saat ini akan dicoba dianalisis mengenai arti data tersebut, sehingga metodenya juga disebut metode deskriptif analitis. sejalan dengan pendapat Winarmo Surahmad (2004:139) mengatakan bahwa ciriciri metode deskriptif sebagai berikut:

1. Memutuskan diri pada pemecahan masalahmasalah yang ada pada masa sekarang, pada masalah-masalah aktual,

2. Data yang dikumpulkan mula-mula disusun, dijelaskan dan kemudian dianalisa.

Metode deskriptif analitis yaitu suatu metode penelitian yang menggambarkan atau menjelaskan data yang sifatnya aktual dan dilanjutkan dengan menganalisis data tersebut untuk mencari hubungan, kaitan dan pengaruh antara variabel yang satu dengan variabel yang lain.

Adapun teknik pengumpulan data yang dilakukan oleh penulis adalah sebagai berikut:

a. Observasi

b. Studi dokumentasi

c. Angket (kuesioner)

Dalam menganalisis data yang diperoleh dalam rangka pengujian hipotesis, data tersebut diolah terlebih dahulu kemudian dianalisis dengan menggunakan metode statistic parametric (skala yang digunakan adalah rasio) untuk menguji hipotesis yang diajukan.

1. Analisis Koefisien Korelasi 
Analisis ini digunakan untuk menentukan tingkat keeratan hubungan antar variabel yang diteliti.

2. Analisis Koefisien Determinasi

Analisis ini digunakan untuk mengetahui besarnya pengaruh perencanaan penjualan terhadap penjualan perusahaan.

3. Uji Signifikan/Uji t

Terkait pengujian hipotesis digunakan uji t. Selanjutnya untuk mengetahui apakah koefisien korelasi memiliki tingkat signifikan dengan cara membandingkan $t$ hitung dengan $\mathrm{t}$ tabel. Menurut Sugiyono (2017:231) kriteria pengujian hipotesis adalah sebagai berikut:

a. Jika $\mathrm{t}_{\text {hitung }}<\mathrm{t}_{\text {tabel}}$, maka $\mathrm{H}_{\mathrm{o}}$ diterima dan $\mathrm{H}_{\mathrm{a}}$ ditolak, artinya perencanaan tidak berpengaruh terhadap pengendalian biaya penjualan pada perusahaan.

b. Jika $\mathrm{t}_{\text {hitung }}>\mathrm{t}$ tabel, maka $\mathrm{H}_{\mathrm{o}}$ ditolak dan $\mathrm{H}_{\mathrm{a}}$ diterima, artinya perencanaan berpengaruh terhadap pengendalian biaya penjualan pada perusahaan.

Dalam pemilihan sampel baru digunakan dalam penelitian apabila populasinya terlalu besar. Sampel diambil harus dapat mewakili populasi penelitian, sehingga dalam menggeneralisasikan hasil penelitian dapat berlaku bagi populasi. Meskipun pengambilan banyak sampel tidak ada ketentuan atau rumus yang berlaku, tetapi Arikunto (2016:107) mengatakan bahwa dalam teknik pengambilan sampel sebagai ancer-ancer jika subjek penelitian kurang dari 100 responden maka lebih baik diambil semua sehingga penelitiannya merupakan penelitian populasi dan jika subjeknya lebih dari 100, maka sampelnya diambil $10-15 \%$ atau $20-25 \%$.

Sehubungan dengan hal tersebut, semua populasi mendapat kesempatan menjadi sampel, dan diambil pada waktu yang sama, maka penulis tetapkan besarnya sampel adalah 12 orang karyawan perusahaan.

\section{HASIL PENELITIAN DAN PEMBAHASAN}

Perencanaan penjualan berdasarkan hasil jawaban responden melalui penyebaran angket dari 12 responden digunakan skala likert. Interpretasi atas jawaban responden per pernyataan dengan perhitungan sebagai berikut (Sudjana, 2000, 77-79):

Rentang $=$ Skor tertingi - skor terendah

Panjang kelas interval =

\section{$\frac{\text { renang }}{\text { banyalkelasintervc }}$}

Skor tertinggi $12 \times 5=60$

Nilai terendah $12 \times 1=12$

Nilai tertinggi - nilai terendah $60-12=$ $\frac{48}{5}=9,3$

Berdasarkan hasil penelitian bahwa perencanaan penjualan di perusahaan dari hasil angket yang dibagikan diketahui hasil sebagai berikut:

Tabel 2

Perencanaan Penjualan

\begin{tabular}{cccccc}
\hline No & Klasifikasi & Skala & Frekuensi & Nilai & \% \\
\hline $\mathbf{1}$ & Selalu & 5 & 98 & 490 & 85,96 \\
$\mathbf{2}$ & Sering & 4 & 14 & 56 & 9,82 \\
$\mathbf{3}$ & Jarang & 3 & 8 & 24 & 4,21 \\
$\mathbf{4}$ & Kadang-kadang & 2 & 0 & 0 & 0 \\
$\mathbf{5}$ & Tidak Pernah & 1 & & 0 & \\
& $\sum$ & & 120 & 570 & 100 \\
\hline
\end{tabular}

Berdasarkan tabel 2 dapat dijelaskan bahwa yang menjawab selalu berjumlah 98 dengan nilai 490 atau $85,96 \%$, yang menjawab sering berjumlah 14 dengan nilai 56 atau $9,82 \%$, yang menjawab kadang-kadang berjumlah 8 dengan nilai 24 atau $4,21 \%$.
Jumlah nilai yang terkumpul seluruhnya berjumlah 570 sedangkan skor ideal 10 x 5 x 12 $=600$. Dengan demikian maka perencanaan penjualan mencapai $\frac{570}{600} \times 10 \sigma_{0}=95 \%$, artinya perencanaan penjualan pada perusahaan 
termasuk dalam kategori sangat baik. Dimana perusahaan melaksanakan langkah-langkah perencanaan penjualan meliputi:

1. Perencanaan penjualan yang dilakukan perusahaan penyusunannya dibantu oleh bagian-bagian lainnya di dalam perdagangan.

2. Dalam merencanakan penjualan perusahaan selalu berdasarkan pendapat para tenaga penjualnya.

3. Perusahaan melakukan survei terhadap para langganan.

4. Metode penjualan yang digunakan perusahaan dapat meningkatkan volume penjualannya.

5. Perusahaan selalu melaksanakan syaratsyarat dalam penjualan.
6. Perusahaan memerlukan modal yang cukup besar untuk menjaga kualitasnya agar tidak menurun.

7. Perusahaan benar-benar memperhatikan faktor-faktor yang mempengaruhi dalam penetapan harga.

8. Perusahaan menjalankan penetapan harga berdasarkan persaingan.

9. Perusahaan melakukan penetapan harga berdasarkan persepsi pembeli.

10.Perusahaan melakukan pengontrolan melalui pencatatan yang dijadikan marketing dari transaksi penjualan yang telah dilakukan.

Sedangkan, hasil tanggapan responden mengenai pengendalian penjualan yang terdiri dari delapan item pertanyaan disajikan dalam tabel dibawah ini.

Tabel 3

Pelaksanaan Pengendalian Penjualan

\begin{tabular}{cccccc}
\hline No & Klasifikasi & Skala & Frekuensi & Nilai & \% \\
\hline $\mathbf{1}$ & Selalu & 5 & 3 & 15 & 5.03 \\
$\mathbf{2}$ & Sering & 4 & 18 & 72 & 24.16 \\
$\mathbf{3}$ & Jarang & 3 & 61 & 183 & 61.41 \\
$\mathbf{4}$ & Kadang-kadang & 2 & 14 & 28 & 9.39 \\
$\mathbf{5}$ & Tidak Pernah & 1 & & 0 & \\
& $\sum$ & & 96 & 298 & 100 \\
\hline
\end{tabular}

Berdasarkan tabel 3 dapat dijelaskan bahwa yang menjawab selalu berjumlah 3 dengan nilai 15 atau $5,03 \%$, yang menjawab sering berjumlah 18 dengan nilai 72 atau $24,16 \%$, yang menjawab kadang-kadang berjumlah 61 dengan nilai 183 atau $61,41 \%$ dan yang menjawab kadang-kadang berjumlah 14 dengan nilai 28 atau 9,39. Jumlah nilai yang terkumpul seluruhnya berjumlah 298 sedangkan skor ideal $8 \times 5 \times 12=480$. Dengan demikian maka pengendalian penjualan mencapai $\frac{298}{480} \times 10 \%=62,08 \%$, artinya perencanaan penjualan pada perusahaan termasuk dalam kategori sedang.

Adapun unsur dalam pelaksanaan pengendalian penjualan yang dilaksanakan perusahaan meliputi:

1. Perusahaan mengawasi berjalannya proses penjualan yang terjadi dan melakukan pencatatan dari hasil pelaksanaan penjualan di lapangan.
2. Perusahaan memberikan pelatihan kepada pekerja dalam menangani cara penggunaan pelanggannya.

3. Perusahaan dan pelanggan tidak akan berakhir dengan selesainya penjualan.

4. Pengendalian akuntansi yang telah dilakukan perusahaan selama ini berjalan cukup baik.

5. Perusahaan menggunakan komputer sebagai pencatat jurnal penjualan.

6. Adanya pengawasan tentang pencatatan yang dilakukan oleh marketing dan pelaporan oleh adminsitrasi.

7. Perusahaan memberikan kebijaksanaan terhadap produk yang akan dijual.

8. Perusahaan melakukan kegiatan operasional memusatkan perhatiannya ke bidang usaha.

Berdasarkan hasil perhitungan di atas koefisien determinasi menunjukkan angka $59,29 \%$. Ini berarti perencanaan penjualan memberikan pengaruh sebesar 59,29\% terhadap pengendalian penjualan sedangkan $40,71 \%$ dipengaruhi oleh faktor lain yang tidak diteliti. 
Berdasarkan perhitungan di atas dapat dijelaskan bahwa thitung sebesar 2,927 pada $\mathrm{dk}=$ $(\mathrm{n}-2)=(12-2)=10$ dan $\alpha=0,05 . \mathrm{t}_{\text {tabel }}$ adalah $\mathbf{2 , 2 2 8}$ dengan demikian maka $t_{\text {hitung }}(2,927)>$ dari $t_{\text {tabel }}(2,228)$, ini berarti Ho ditolak dan $\mathrm{Ha}$ diterima. Jadi hipotess yang diajukan diterima, yaitu perencanaan pencjualan berpengaruh positif terhadap pengendalian penjualan pada perusahaan.

Pengendalian terhadap penjualan merupakan suatu hal yang sangat penting, agar dapat dicapai suatu hasil pengembalian yang sebaik-baiknya atas investasi. Jika perusahaan ingin mencapai penjualan yang menguntungkan, perusahaan harus dapat mengetahui produk manakah yang memberikan kontribusi paling besar terhadap laba yang diperoleh. Hal ini berarti memerlukan analisa terperinci mengenai penjualan. Analisa penjualan dinyatakan dalam satuan fisik, dalam jumlah uang, atau kedua-duanya. Analisa penjualan meliputi penelaahan secara keseluruhan mengenai realisasi volume penjualan yang sesungguhnya telah dicapai, untuk selanjutnya menemukan kekuatankekuatan dan kelemahan-kelemahan dalam penjualan. Telaah yang lain menunjukkan hubungan dengan anggaran atau standar baku, laba kotor, biaya penjualan dan/atau laba bersih. Tujuan analisis penjualan dilakukan untuk mengetahui apakah ada perbedaan antara perencanaan dengan realisasi penjualan, dan mencari penyebab dari perbedaan-perbedaan tersebut.

Setelah dilakukannya analisa penjualan, maka perusahaan akan mengambil kebijaksanaan berkaitan dengan perbedaan yang terjadi. Perbedaan antara angka rencana dengan angka realisasi merupakan suatu penyimpangan dan penyimpangan ini sebenarnya tidak akan terjadi jika antara realisasi dengan rencananya sama. Karena perusahaan sebelum menyusun suatu rencana penjualan, sudah mempertimbangkan segala sesuatunya bahwa apa yang direncanakan akan tercapai sesuai dengan kapasitas perusahaan.

Oleh karena itu jika seandainya ada penyimpangan maka penyimpangan tersebut harus dikaji dan dicari penyebabnya. Bisa saja penyimpangan itu karena keadaan ekonomi yang tidak menentu, minat konsumen atau pihak manajemen membuat taksiran yang tidak tepat mengenai penjualan. Jika penyimpangan yang terjadi menguntungkan perusahaan, tidak akan menimbulkan masalah.
Namun, jika penyimpangan dapat merugikan perusahaan beberapa kebijakan yang dapat dilakukan perusahaan diantaranya:

a. Menyesuaikan hasil kerja atau aktifitas pelaksanaan terhadap rencana yang telah ditetapkan.

b. Memperbaiki strategi penjualan.

c. Menurunkan rencana penjualan yang tidak tercapai.

d. Mempromosikan produk perusahaan.

e. Pelatihan tenaga-tenaga wiraniaga agar mempunyai keahlian dalam menarik minat konsumen untuk melakukan pembelian.

(Siagian, SP. 2004:36)

\section{PENUTUP}

Berdasarkan hasil penelitian yang dilakukan maka ditarik kesimpulan sebagai berikut:

1. Perencanaan penjualan pada perusahaan sudah dilaksanakan cukup baik sesuai standar baku. Hal ini terlihat adanya: (1) perencanaan anggaran penjualan; (2) syarat penjualan; dan (3) kebijaksanaan penetapan harga

2. Pengendalian penjualan yang dilakukan oleh perusahaan selama lima tahun terakhir yaitu dari tahun 2008-2012 mengalami peningkatan. Hal ini disebabkan oleh pelaksanaan pengendalian penjualan melalui (1) pelaksanaan penjualan; (2) pencatatan dan pelaporan penjualan; (3) analisa perbandingan rencana dan realisasi penjualan; dan (4) kebijaksanaan perusahaan.

3. Berdasarkan hasil perhitungan dengan mengunakan uji $\mathrm{t}$ dapat dilihat bahwa $\mathrm{t}$ hitung sebesar 2,927>t tabel sebesar 2,228 sehingga dari hasil tersebut hipotesis yang diajukan oleh penulis diterima dengan kata lain perencanaan penjualan berpengaruh signifikan terhadap pengendalian penjualan.

Berdasarkan kesimpulan di atas, saran yang dapat penulis sampaikan adalah sebagai berikut:

1. Agar perencanaan penjualan yang dilaksanakan oleh perusahaan tetap dipertahankan

2. Agar pengendalian penjualan tetap berjalan, pimpinan perusahaan harus memperhatikan perkembangan perusahaan.

3. Agar perusahaan tetap beroperasi dengan baik sebaiknya perusahaan memelihara dan meningkatkan kualitas SDM yang ada sesuai dengan profesionalisasinya 


\section{DAFTAR PUSTAKA}

Winarno, Surakhmad. 2004. Pengantar Penelitian Ilmiah, Dasar, Metode, dan Teknik. Bandung: Tarsito.

Sugiyono. 2017. Metode Penelitian Bisnis. Bandung: Alfabeta.

Arikunto, Suharsimi. 2016. Prosedur Penelitian Suatu Pendekatan Praktek. Jakarta: Rineka Cipta.

Sudjana, 2000. Metode Statistika. Bandung: Gramedia Pustaka Utama.

Basu Swastha,2011.Manajemen Penjualan. edisi ke-3, Yogyakarta: BPFE.

Horngren, Charles T.,Terj.2009. Pengantar Akuntansi Manajemen, edisi ke-6, Jilid I, Alih Bahasa Frederikson Saragih, Jakarta: Penerbit Erlangga,

Willson, James D., dan John B. Campbell. 2011. Controllership: Tugas Akuntan Manajemen, edisi ke-3, oleh Gunawan Hutauruk, Jakarta: Penerbit Erlangga, 1995.

Siagian, Sondang P. 2014. Organisasi Kepemimpinan dan Perilaku Administrasi. Jakarta : Gunung Agung. 
